\title{
Production of biochars derived from sewage sludge and orange peels
}

Produção de biocarvão a partir de lodo de esgoto e de cascas de laranja

\author{
Larissa Firmino de Lima' \\ Victória Regina Celso Monteiro" \\ Carlos Eduardo Rodrigues Barquilha'"I \\ Maria Cristina Borba Braga'v
}

\begin{abstract}
The accumulation of waste is associated with several environmental and public health impacts. In contrast, the circular economy emerges as a new paradigm to return waste to the production chain. An alternative for the reinsertion of these materials to the production cycle is their conversion into biochar by pyrolysis. Thus, this study aimed at producing, characterizing, and comparing biochars obtained from two different matrices: sewage sludge and orange peels. Temperatures of pyrolysis for the sludge samples were $450{ }^{\circ} \mathrm{C}(\mathrm{BL} 450)$ and $650^{\circ} \mathrm{C}$ (BL650), whereas for the orange peels were $400^{\circ} \mathrm{C}$ (BC400) and $600^{\circ} \mathrm{C}(\mathrm{BC} 600)$. The characterization of both biochars was carried out by scanning electron microscopy (SEM) and energy-dispersive X-ray spectroscopy (EDS). The yield of production was also determined, whose values were $32 \%$ for BC $400,28 \%$ for BC600, 46\% for BL450, and 38\% for BL650. Electron micrographs allowed the identification of pores in biochars BC400 and BC600. At this stage, it was not possible to identify pores on the surfaces of biochars BL450 and $B L 650$. Their surfaces appear to be heterogeneous and asymmetric. The results produced by EDS analysis allow pointing out that there was an absence of trace metals. However, it was observed the presence of compounds potentially beneficial to the soil and plants, which is of particular importance since they can act as binders in the adsorption process. Moreover, due to their carbonaceous composition, biochars are resistant to decomposition and hence can contribute to carbon sequestration. Biochar yields indicated a reduction in the mass of waste, which can be advantageous for handling and transportation. As a result, the production of biochar from non-conventional materials, such as sewage sludge and orange peels can be seen as an attractive alternative for waste management. In particular, because it is related to the reintroduction of these materials in the production chain, and thus comply with the concept of the circular economy.
\end{abstract}

Keywords: Reuse of waste; Circular economy; Pyrolysis

\section{Resumo}

O acúmulo de resíduos no meio ambiente acarreta diversos impactos ambientais e à saúde pública. Em contrapartida, a economia circular surge como um novo paradigma que busca o retorno dos resíduos à cadeia

I Parana Federal University, Curitiba, PR, Brazil - larissa.Iflima@gmail.com.

II Parana Federal University, Curitiba, PR, Brazil - victoriarcmonteiro@gmail.com.

III Parana Federal University, Curitiba, PR, Brazil, Brasil - ce.barquilha@gmail.com.

IV Parana Federal University, Curitiba, PR, Brazil - crisbraga@ufpr.br. 
produtiva. Uma alternativa para a reinserção destes materiais ao ciclo produtivo baseia-se na sua transformação em biocarvão via pirólise. Assim, o objetivo principal desta pesquisa foi produzir biocarvão, a sua caracterização inicial e a comparação entre os biocarvões obtidos a partir de duas matrizes distintas: lodo de esgoto e cascas de laranja. As amostras de lodo foram pirolisadas a $450^{\circ} \mathrm{C}$ (BL450) e $650^{\circ} \mathrm{C}(\mathrm{BL} 650)$. Enquanto as temperaturas utilizadas para as cascas de laranja foram $400^{\circ} \mathrm{C}(\mathrm{BC} 400)$ e $600^{\circ} \mathrm{C}(\mathrm{BC} 600)$. Foram determinados os rendimentos da produção dos biocarvões e realizadas análises de microscopia eletrônica de varredura (MEV) e espectroscopia de raios $X$ por dispersão em energia (EDS). Os rendimentos obtidos foram de $32 \%$ (BC400), $28 \%$ (BC600), 46\% (BL450) e 38\% (BL650). A presença de poros foi identificada nas fotomicrografias do BC400 e BC600. Contudo, para o BL450 e BL650, não foram observados poros mas, apenas, superfícies heterogêneas e assimétricas. A análise de EDS mostrou a ausência de metais-traço e a presença de compostos potencialmente benéficos ao solo e às plantas, que podem atuar como ligantes no processo de adsorção. Devido a sua composição majoritariamente carbonácea, os biocarvões são resistentes à decomposição e podem atuar como sequestradores de carbono. Além disso, os rendimentos obtidos indicam redução de massa dos resíduos, o que pode facilitar o manuseio e o transporte. Dessa forma, a produção de biocarvão a partir de materiais não convencionais, como lodo de esgoto e cascas de laranjas, apresenta-se como alternativa atrativa para a gestão e o gerenciamento de resíduos, por facilitar a reintrodução desses materiais na cadeia produtiva, estando de acordo com o conceito de economia circular.

Palavras-chave: Reaproveitamento de resíduos; Economia circular; Pirólise 


\section{Introduction}

Population growth and high demand for products and services are directly related to the increase in waste generation. Consequently, the accumulation of waste in the environment is associated with several environmental and public health impacts, which compromises the availability of natural resources, contributes to soil and water contamination, emission of greenhouse gases, and favors the dissemination of pathogenic organisms (KJELDSEN et al., 2002; MARTINS et al., 2017; COSTA et al., 2019). Therefore, adequate waste management, in addition to the search for more sustainable alternatives for solid waste disposal, is paramount. Furthermore, in opposition to the linear economy, which emphasizes the logic of exploitation-use-disposal, the circular economy emerges (HOMRICH et al., 2018; MIRABELLA et al., 2014). This approach by the circular economy demands a change of paradigm in which not only new criteria for the design and conception of a product is to be practiced but also its reinsertion into the production chain. Thus, there is a need for a new model to deal with production, consumption, and disposal, which are the main points to be considered together with energy minimization.

The reintroduction of recyclable waste in the production cycle can occur through recycling and reuse. The biodegradable portion, in turn, can be recycled in the environment via application on soil, composting, and digestion (MACARTHUR, 2015). On the other hand, some biodegradable waste, such as citrus fruit waste and sewage sludge, present specificities that restrict their use. The first, because of the presence of substances that impairs composting, and the latter because of the presence of pathogens.

The complexity of the treatment and disposal of sewage sludge is related to the technical, economic, environmental, and legal aspects. In practice, the alternative that considers the application of sewage sludge on soils presents challenges. This is due to the requirement of adequate conditions to comply with legal aspects as well as to guarantee adequate sanitary characteristics. Therefore, increasing environmental and control restrictions make alternatives for sewage sludge treatment and disposal more limited, and, thus, new recycling alternatives must be found (MARTIN et al., 2004). 
Among the residues of citrus fruits, orange peels are the most abundant. Brazil is the world's largest orange producer, with a total of 17.5 million tons per year, with the majority of the crop destined for juice production (IBGE, 2017). The residue produced after the extraction of the juice represents about $50 \%$ of the mass of the fresh fruit and is presented as peels (60\% to $65 \%$ ), pulp (30\% to $35 \%$ ) and seeds (0 to $10 \%$ ) (CYPRIANO et al., 2018). Despite being an organic waste, composting facilities and biodigesters are not the most suitable alternatives. This is due to the presence of D-limonene, the main essential oil, which is toxic to microorganisms. Additionally, the high acidity, characteristic of citrus fruits, contributes to a decrease in $\mathrm{pH}$ and is also harmful to the microbiota (MARTíNEZ et al., 2018).

Thus, based on the concepts of the circular economy, an alternative for the reuse of both orange peels and sewage sludge is their conversion into biochar by pyrolysis, which is a thermal treatment carried out under controlled temperature and low oxygen concentration. The result is a biosolid that presents a high volume of pores and the presence of functional groups on its surface. The biochar can be used as an adsorbent for pollutant removal, to improve soil quality and increase carbon sequestration (STEINER, 2008; AHMAD et al., 2014; BATISTA et al., 2018; MAROUŠEK et al., 2019).

Pyrolysis of biomass favors carbon sequestration because the resulting product is a solid material mainly composed of carbon and highly resistant to the decomposition process. As a result, there is a delay in returning the carbon to the atmosphere due to the stability of the biochar when compared with that of the raw material (STEINER, 2008).

The biochar can contribute to soil amendment in several ways due to its high carbon content, high porosity, low density, and the presence of functional groups. Among the contributions, it facilitates microbial activity, improves carbon enrichment, reduces soil density and nutrient leaching, increases soil temperature, water retention, and air-soil exchange, as well as accelerates nutrient transport and mineralization necessary to plant growth (BATISTA et al., 2018; MAROUŠEK et al., 2019).

Moreover, the high surface area of the biochar due to the volatilization of organic matter and the formation of aromatic and polymeric structures from carbonization allows the use of the biochar as an adsorbent material. The use of biochar for the adsorption of 
contaminants is also a low-cost alternative for the treatment of various wastewaters (UCHIMIYA et al., 2011; AHMAD et al., 2014).

Based on the need for waste management practices aligned with the precepts of the circular economy, as well as the information previously presented, the evaluation of the characteristics and the potential of biochars produced from waste generated in large quantities can be justified. Therefore, the aim of this study was to produce, compare, and characterize biochars produced from two different biodegradable matrices, sewage sludge, and orange peels.

\section{Material and Methods}

\subsection{Waste collection}

Sludge samples were collected in a sewage treatment plant operating by activated sludge, located in Curitiba - Brazil, after the dewatering stage and before the application of the lime. Orange peels (Citrus sinensis L. Osbeck) were collected in a fruit and vegetable shop located in Curitiba's Metropolitan Area - Brazil.

\subsection{Sample preparation}

The sludge was oven-dried (Lucadema brand, model LUCA-80/42) under a temperature of $105^{\circ} \mathrm{C}$ for 72 hours, until completely dry (AGRAFIOTI et al., 2013; CHEN et al., 2015; PRADO, 2018).

The orange peels were cleaned to remove membranes and seeds, and then $8-\mathrm{mm}$ particles were produced by cutting them with a vegetable cube cutter. Subsequently, the cubs were washed to remove impurities and oven-dried at $105^{\circ} \mathrm{C}$ for 24 hours, according to the methodology presented by Mireles et al. (2019).

After drying, the solids were placed in a desiccator until room temperature was reached. The moisture content of both sewage sludge and orange peels was determined by gravimetry, as presented in the Standard Methods for the Examination of Water and Wastewater (APHA, 1999). 


\subsection{Biochar production}

Sludge samples were placed in porcelain covered crucibles, weighed, sprayed with nitrogen gas for 2 minutes, according to a procedure adapted from Prado (2018), and then wrapped in aluminum foil to reduce oxygen contact, according to Chemerys and Baltrènaitè (2017). The crucibles containing the dry sludge were muffled in a furnace (Coel brand, model GMP-2), under the temperature of $450^{\circ} \mathrm{C}$ for 1 hour (BL450), and under $650^{\circ} \mathrm{C}$ for 1.5 hours (BL650). The thermal treatment was carried out under a heating rate of $15^{\circ} \mathrm{C} / \mathrm{min}$. The time of pyrolysis and the temperatures were determined based on results by Prado (2018) and Wang et al. (2019). The crucibles were removed from the muffle furnace, placed in a desiccator until room temperature was reached. Subsequently, to obtain the biochar from sludge, the masses were weighed, ground to a powder in a ceramic mortar and pestle, and sieved in a $0.425 \mathrm{~mm}$ mesh.

Samples of dry orange peels were placed in porcelain covered crucibles (TRAN et al., 2016), weighed and wrapped in aluminum foil to reduce oxygen contact (HU et al., 2020). The pyrolysis of the orange peels was carried out under temperatures of $400^{\circ} \mathrm{C}(\mathrm{BC} 400)$ and $600^{\circ} \mathrm{C}$ (BC600), in both cases, for 1 hour. The thermal treatment was carried out under a heating rate of $10{ }^{\circ} \mathrm{C} / \mathrm{min}$, according to Feitosa et al. (2019). After pyrolysis, the crucibles were removed from the muffle furnace and placed in a desiccator until room temperature was reached. As a result of the thermal treatment, it was observed a reduction in the particle size. At this point, particles measuring $5 \mathrm{~mm}$ by $5 \mathrm{~mm}$ were named granular biochar.

After the preparation stage, all biochars produced were kept in sterile plastic bottles until further use.

\subsection{Biochar characterization}

The yield of biochars was determined by the ratio of the mass of produced biochar to the dry mass of orange peels (AGRAFIOTI et al., 2013). The weighing of all samples was carried out on a precision analytical scale (Shimadzu).

The morphology and the surface chemistry of the biochars produced were carried by scanning electron microscopy (SEM) and energy-dispersive X-ray spectroscopy (EDS). These analyses were carried out at the Electron Microscopy Center - UFPR (CME/UFPR), using a 
$15 \mathrm{kV}$ electron microscope coupled to an X-ray dispersive energy detector (Jeol brand, model JSM-636 OLV). The biochar samples were fixed on aluminum supports and, after the EDS analysis, were metalized with gold. Photomicrographs were produced under magnifications of 1,000x; 5,000x; and 15,000x for the sludge biochars, whereas magnifications of 50x; 250x; and $1,000 x$ were produced for orange peel biochars.

\subsection{Data processing}

The pyrolysis of orange peels, which resulted in the biochars BC400 and BC600, was carried out in triplicate. The average yield for each temperature used in the thermal treatment was calculated by arithmetic mean, and the resulting values were rounded to the nearest whole number. The same approach was used for the biochars from sewage sludge (BL450 and (BL650). The data obtained from the energy-dispersive X-ray spectroscopy analyzes was plotted using the Origin Pro 8.5 software.

\section{Results and Discussion}

\subsection{Moisture of the raw materials}

The moisture content of sludge was $86.2 \%$, which equals a solids content of about 14\%, below the range of the solids content reported by Andreoli et al. (2014), which was between $20 \%$ and $30 \%$ for the sewage sludge after the stage of centrifugation. Nevertheless, Agrafioti et al. (2013), also using aerobic sewage sludge, reported a moisture content of $84.5 \%$, a value close to that obtained in this study.

The moisture content of the orange peels was $79.1 \%$, which was close to the value reported by Pellera et al. (2012) of $84.2 \%$. These authors oven-dried orange residues at $80^{\circ} \mathrm{C}$ for 24 hours, and in this case, the high moisture content of the orange peels could have been reduced by a previous sun-drying of samples, as performed by Bhattacharjee and Biswas (2019).

\subsection{Biochars yield}

The average yield obtained for the conversion of dry orange peels into biochar was $32 \%$ for $\mathrm{BC} 400$ and $28 \%$ for BC600, whereas for the sludge biochars was $46 \%$ for BL450 and 
38\% for BL650. The yield of biochar BL450 was 46\%, which was 11 percentage points higher than that reported by Agrafioti et al. (2013), who produced biochar from sludge pyrolyzed at $400^{\circ} \mathrm{C}$ for $1 \mathrm{~h}$. On the other hand, the yield of $38 \%$ for the biochar from sludge BL650 was 16 percentage points lower than that reported by Chen et al. (2015), who produced biochar from sludge pyrolyzed at $650^{\circ} \mathrm{C}$ for $2 \mathrm{~h}$. This variation could have been associated with inherent characteristics of sewage sludge, which is related to the region, the habits of the population, and the technology used in sewage treatment. It was observed a difference of yield of 8 percentage points between biochars BL450 and BL650. This may be related to the increase in the temperature of pyrolysis, which is corroborated by the results produced by other authors (AGRAFIOTI et al., 2013; DING et al., 2017).

Regarding the production of biochars from orange peels, the yield was $32 \%$ for the BC400. However, if the result is compared with that of $34 \%$ obtained by Tran et al. (2016), the difference in the yield can be considered negligible. In this case, the temperature of pyrolysis was $400^{\circ} \mathrm{C}$, and the time used was $2 \mathrm{~h}$.

It can also be pointed out that the yield obtained for biochar BC600 was 28\%, practically the same as that obtained by Chen and Chen (2009) (27\%), whose biochar was also produced at $600^{\circ} \mathrm{C}$ for $1 \mathrm{~h}$. The findings are similar to those obtained for the biochar from sludge. It was also observed that there was a reduction in the yield when biochars BC400 and BC600 were compared. This result can be regarded as a loss of volatile matter, which is a result associated with the destruction of molecules of cellulose and hemicellulose, caused by the increase in temperature (CHEN and CHEN, 2009; TRAN et al., 2016).

\subsection{Scanning electron microscopy (SEM)}

Photomicrographs of biochars BC400 and BC600 from orange peels are presented in Figures $1 \mathrm{a}, \mathrm{b}, \mathrm{c}$, and Figures $1 \mathrm{~d}, \mathrm{e}, \mathrm{f}$, respectively. It is possible to observe macropores in biochars produced under both temperatures.

Relatively smaller pores can be observed in Figures $1 \mathrm{~b}$ and 1e (250x magnification) and in Figures $1 c$ and $1 f(1,000 x$ magnification), which could have resulted from the thermal treatment. It can be pointed out that the resulting porous structure favors the use of biochars in soil amendment and also provides a material that can be used as an adsorbent for different contaminants. According to Lam et al. (2018), the use of biochars as adsorbents is 
of particular importance because the pores increase the surface area, which may be associated with greater availability of active sites.

Photomicrographs of biochars from sewage sludge, i.e., BL450 and BL650, are shown in Figure 2, in which asymmetric and irregular particles can be observed under the lowest magnification (Figures 2a and 2d). According to Ding et al. (2016), different sizes and shapes of biochar particles can be influenced by the steps of sample preparation, such as grinding and washing.

The photomicrographs produced under the highest magnifications allow observing that the surface of the biochar from sewage sludge is heterogeneous and present adhering particles (Figures 2b, 2c, 2e, and 2f). This result can be explained by the presence of particles in samples of sewage, which were removed by pyrolysis.

Mocelin (2007) also observed irregular shapes and undefined particles in biochar from sewage sludge pyrolyzed at $700^{\circ} \mathrm{C}$. Costa Neto et al. (2018), in turn, observed, in biochar from sewage sludge pyrolyzed at $500^{\circ} \mathrm{C}$, rough surface, with adhering particles and irregular shapes in addition to non-visualization of pores.

Figure 1 - SEM micrographs of biochars $B C 400(a, b, c)$ and the $B C 600(d, e, f)$

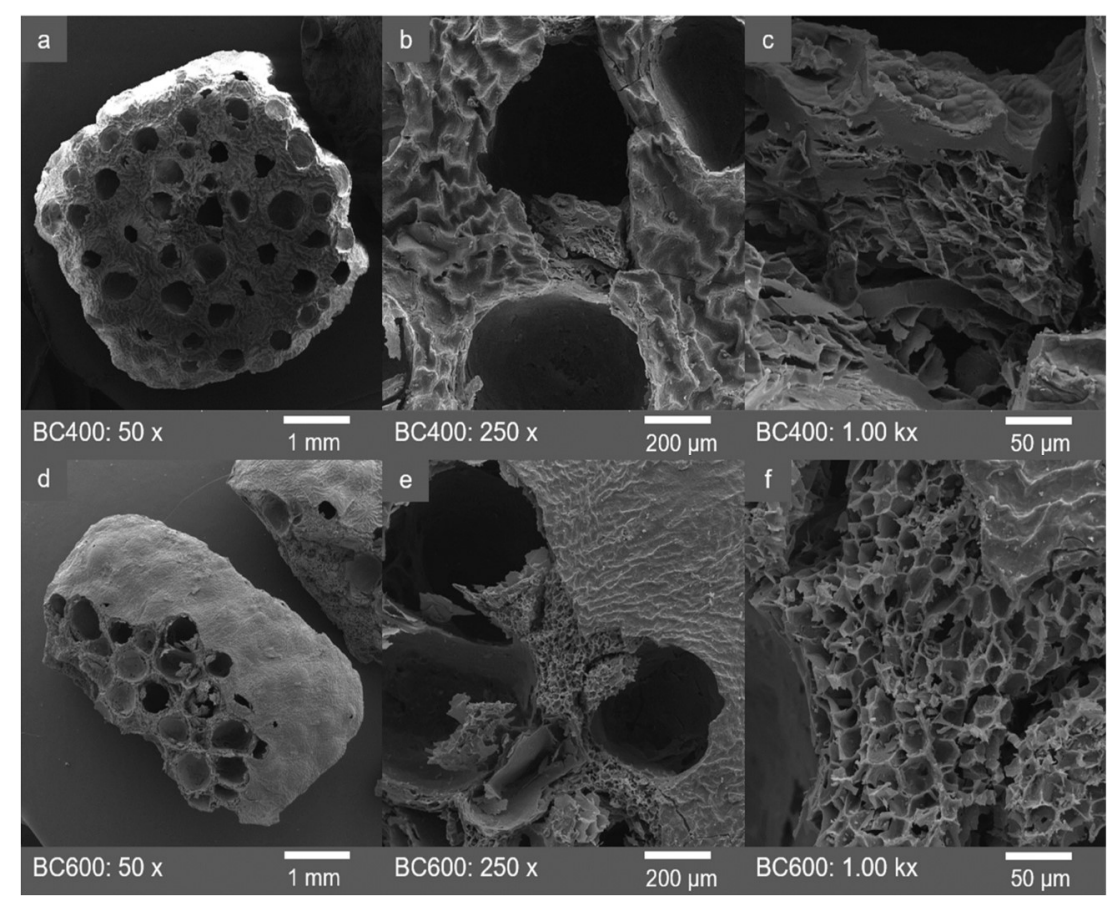

Note: magnifications of $50 x(a, d), 250 x(b, e)$ and $1,000 x(c, f)$ 
Figure 2 - SEM micrographs of the samples from the $B L 450(a, b, c)$ and the $B L 650(d, e, f)$ biochars

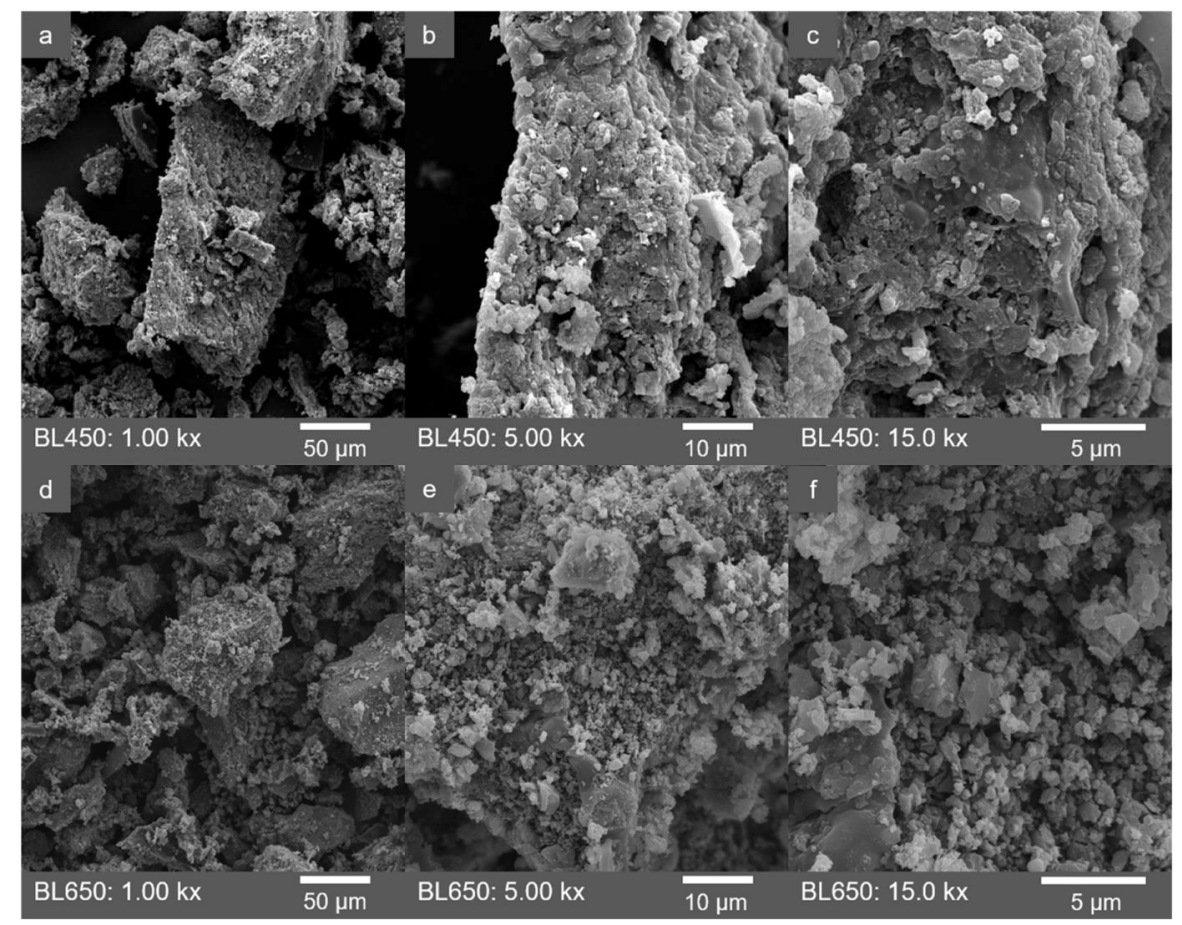

Note: magnifications of $1,000 \times(a, d), 5,000 \times(b, e)$ and $15,000 \times(c, f)$

\subsection{Energy dispersive X-ray spectroscopy (EDS)}

The results produced by energy-dispersive X-ray spectroscopy for biochars from orange peel suggest that the main elements present on the surface of BC400 were carbon (75.7\%), oxygen (16.9\%), potassium (2.5\%), and calcium (1.6\%) (Figure 3). The BC600 also presented carbon (82.2\%), oxygen (8.5\%), potassium (5.3\%), and calcium (2.7\%), however, with additional small percentages of phosphorus $(0.5 \%)$ and magnesium $(0.4 \%)$. In both cases, the increase in the percentage of carbon and the decrease in the percentage of oxygen are directly related to the increase in the temperature of pyrolysis. Similar results were observed by Chen and Chen (2009) and Tram et al. (2016).

Regarding the biochars from sewage sludge, as presented in Figure 4, it is noteworthy that the elements identified in larger quantities were carbon (48.8\%), oxygen (31.7\%), silicon (5.8\%), and aluminum (5.3\%). Other elements were also identified, including phosphorus, iron, calcium, magnesium, potassium, titanium, sulfur, chlorine, and sodium.

Similar results were observed for the biochar BL650 (Figure 4). The elements identified in larger amounts were carbon (41.9\%) and oxygen (26.3\%), and in smaller amounts silicon 
(6.2\%), phosphorus (6.0\%), aluminum (5.8\%), and iron (5.0\%). In lower proportions, calcium, magnesium, potassium, titanium, chlorine, sulfur, and sodium were also identified.

Results produced by Mocelin (2007), who also studied pyrolyzed aerobic sludge and characterized the biochar produced by EDS, showed the presence of carbon and oxygen, and also magnesium, aluminum, silicon, phosphorus, sulfur, calcium, and iron. These results corroborate those produced by this research.

Data presented in Figure 4 allow the observation of a reduction in the peaks of carbon and oxygen for the biochar BC600, which is in agreement with results by Lehmann and Joseph (2009), who pointed out that the loss of these elements occurs during pyrolysis and causes a reduction in the peaks.

Figure 3 - Energy-dispersive X-ray spectroscopy (EDS) of biochars BC400 and BC600

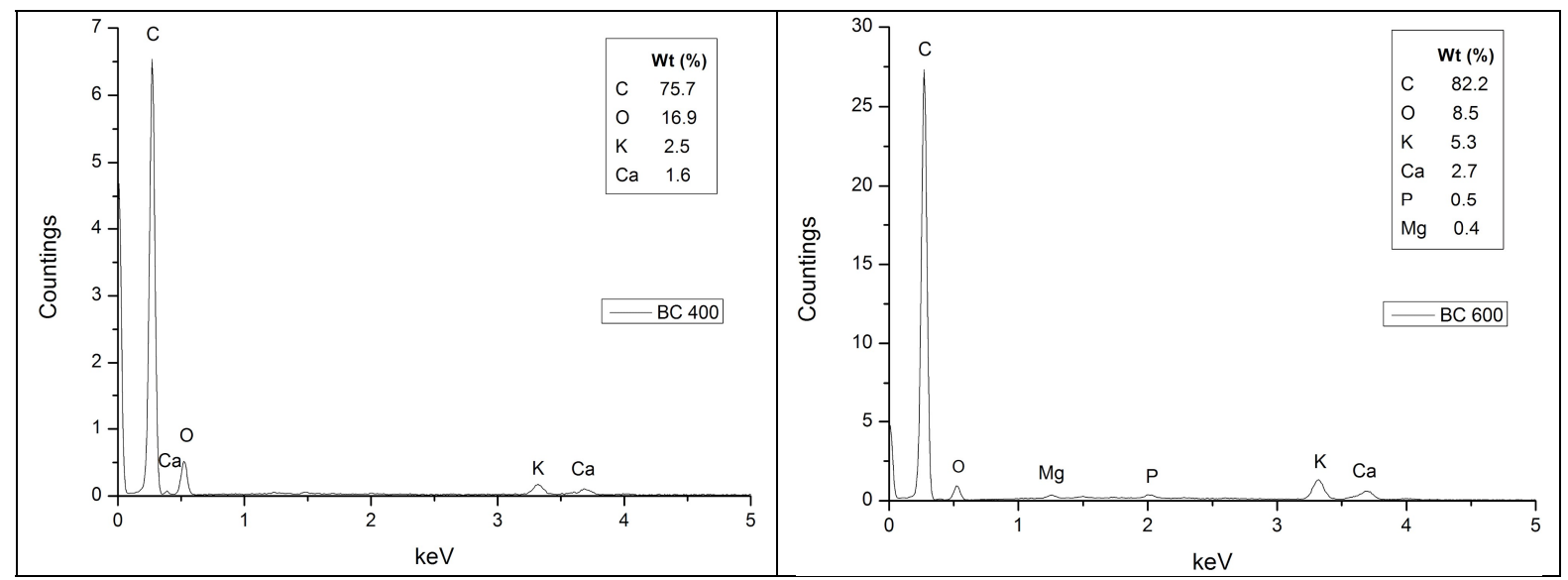

Figure 4 - Energy-dispersive X-ray spectroscopy (EDS) of biochars BL450 and BL650

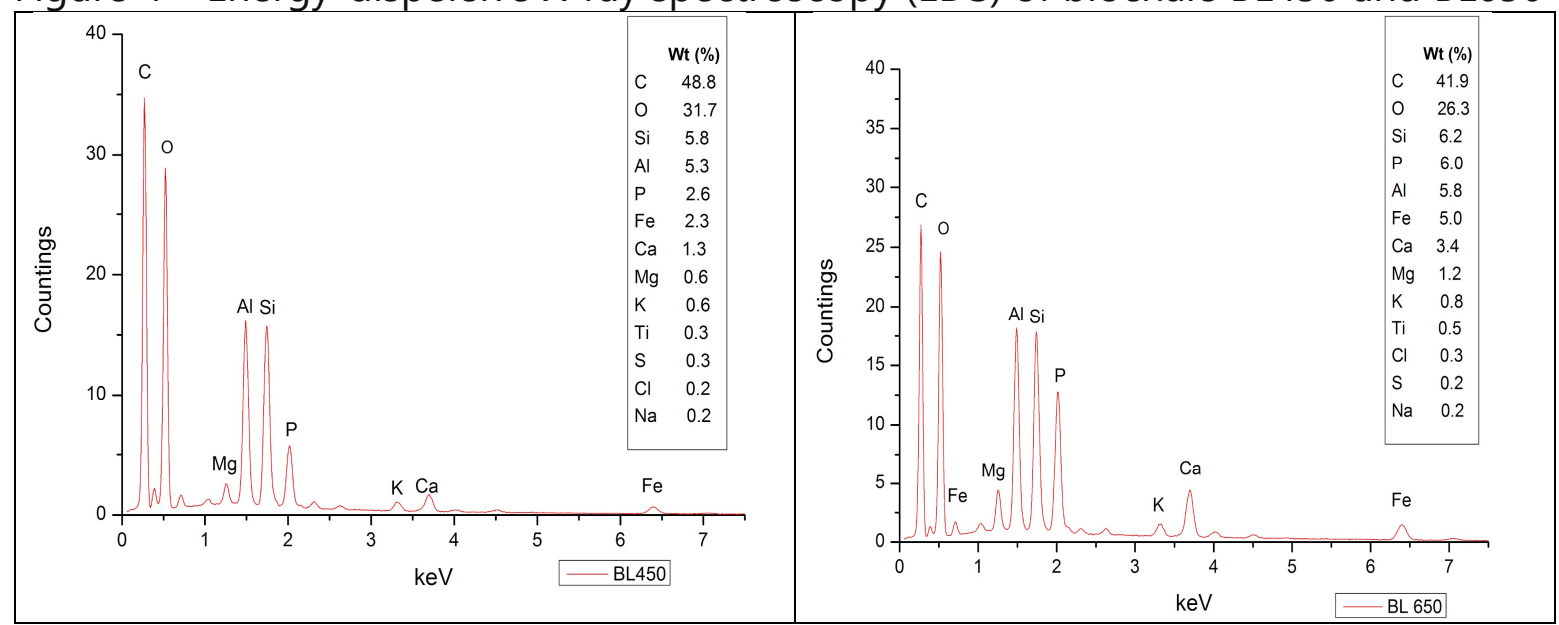


Findings based on the results provided by SEM were corroborated by those produced by EDS. It can be stressed that the presence of elements such as silicon and aluminum are characteristic of adhering mineral particles. Therefore, although it has not been possible to observe pores on the surface of biochars BL450 and BL650, these elements can act as binders and potentially adsorb contaminating substances.

\section{Conclusion}

Biochars produced from two matrices, i.e., sewage sludge and orange peels did not present trace metals; however, macro and micronutrients were observed in proportions that can be beneficial for soil and plants. According to the results produced, which were corroborated by the association of different analyses and, in particular, by findings by other authors, the biochars can act as binders in the adsorption of pollutants.

It is worth mentioning that the presence of pores identified in biochars from orange peels can improve the performance in soil amendment as well as in adsorption processes to test the efficiency to remove contaminants from wastewaters.

It is worth mentioning that the presence of pores identified in biochars from orange peels can be associated with an improvement in the performance of the biosolids when used either as soil amender or as an adsorbent. The pores increase the surface area as well as the availability of active sites. In particular, if the characteristics of the soil are of concern, the pores present in biochars are important for the retention of water and nutrients, for the reduction of soil density, and also for the development of microorganisms.

Moreover, it was observed that the biochar from sewage sludge showed higher yield of mass than that from orange peels. This is likely due to the presence of inorganic compounds, which were also identified by the results of EDS analysis.

Consequently, the pyrolysis of non-conventional, abundant and low-cost materials, such as sewage sludge and orange peels, could be an alternative to minimize the need for landfill disposal of these wastes. Additionally, the production of biochar enables the commercial valuation of these biodegradable wastes and their reintroduction in the production chain, which would be in accordance with the precepts of the circular economy. 
Additionally, the production of biochar enables commercial valuation of these biodegradable wastes and their reintroduction in the production chain. Most importantly, this would be in accordance with the precepts of the circular economy.

\section{Acknowledgments}

The authors gratefully acknowledge the support provided by the Coordination for the Improvement of Higher Education Personnel (Coordenação de Aperfeiçoamento de Pessoal de Nível Superior - CAPES), Water Resources and Environmental Engineering Post-Graduate Program (PPGERHA-UFPR) and the Electron Microscopy Center at UFPR (CME/UFPR).

\section{References}

AGRAFIOTI E.; BOURAS G.; KALDERIS D.; DIAMADOPOULOS E. Biochar production by sewage sludge pyrolysis. J. Anal. Appl. Pyrolysis. 2013; 101:72-8.

AHMAD M.; RAJAPAKSHA A.U.; LIM J.E.; ZHANG M.; BOLAN N.; MOHAN D. et al. Biochar as a sorbent for contaminant management in soil and water: a review. Chemosphere. 2014; 99:19-33.

ANDREOLI C.V.; SPERLING M.V.; FERNANDES F. Lodo de esgotos: tratamento e disposição final. 2nd ed. Belo Horizonte: Universidade Federal de Minas Gerais; 2014.

APHA. Standard Methods for the Examination of Water and Wastewater. $21^{\text {th }}$ ed. Washington: APHA - American Public Health Association; 1999.

BATISTA E.M.; SHULTZ J.; MATOS T.T.; FORNARI M.R.; FERREIRA T.M.; SZPOGANICZ B.; et al. Effect of surface and porosity of biochar on water holding capacity aiming indirectly at preservation of the Amazon biome. Sci. Rep. 2018; 8(1):1-9.

BRASIL, Ministério do Desenvolvimento Regional. Secretaria Nacional de Saneamento - SNS. Sistema Nacional de Informações sobre Saneamento: 24a Diagnóstico dos Serviços de Água e Esgotos - 2018. Brasília: SNS/MDR; 2019.

CHEN B.; CHEN Z. Sorption of naphthalene and 1-naphthol by biochars of orange peels with different pyrolytic temperatures. Chemosphere. 2009; 76(1):127-33.

CHEN H.; ZHAI Y.; XU B.; XIANG B.; ZHU L.; QIU L.; et al. Characterization of bio-oil and biochar from high-temperature pyrolysis of sewage sludge. Environ. Technol. 2015; 36(4):470-8. 
CHEMERYS V.; BALTRĖNAITÉ E. Pine-derived biochar as option for adsorption of $\mathrm{Cu}, \mathrm{Zn}, \mathrm{Cr}$, $\mathrm{Pb}, \mathrm{Ni}$ and decreasing of BOD5 in landfill leachate. Future of Lithuania. 2017; 9(4):406-12.

COSTA A.M.; ALFAIA R.G.; CAMPOS J.C. Landfill leachate treatment in Brazil-An overview. J. Environ. Manage. 2019; 232:110-6.

COSTA NETO D.S.; SOUZA A.O.; SANTOS T.S.M. Adsorvente Preparado a Partir de Lodo De Esgoto e sua Aplicação para a Remoção de Tartrazina. In: Anais do 120 Congresso Brasileiro sobre Adsorção; 2018 Apr 23-25; Gramado, Brasil. p. 1-6.

CYPRIANO D.Z.; DA SILVA L.L.; TASIC L. High value-added products from the orange juice industry waste. Waste Manage. 2018; 79:71-8.

DING Z.; WAN Y.; HU X.; WANG S.; ZIMMERMAN A.R.; GAO B. Sorption of lead and methylene blue onto hickory biochars from different pyrolysis temperatures: importance of physicochemical properties. J. Ind. Eng. Chem. 2016; 37:261-7.

FEITOSA A.A.; RITTER E.; TEIXEIRA W.G.; DE REZENDE F.A.; KERN J. Sorption of Ammonium in Banana Peel and Orange Bagasse Biochars. In: Zhan L, Chen Y, Bouazza A, editors. Proceedings of the 8th International Congress on Environmental Geotechnics Volume 1. 2018 out 28 - nov 01; Hangzhou, China: Environmental Science and Engineering. Springer, Singapore; 2019.

HOMRICH A.S.; GALVAO G.; ABADIA L.G.; CARVALHO M.M. The circular economy umbrella: Trends and gaps on integrating pathways. J. Cleaner Prod. 2018; 175:525-43.

HU X.; ZHANG X.; NGO H.H.; GUO W.; WEN H.; LI C. et al. Comparison study on the ammonium adsorption of the biochars derived from different kinds of fruit peel. Sci. Total Environ. 2020; 707:135544.

IBGE - Instituto Brasileiro de Geografia e Estatística. Produção Agrícola Municipal [Internet]. Rio de Janeiro: IBGE; 2017 [cited 2020 May 10]. Available from: https://biblioteca.ibge.gov.br/visualizacao/periodicos/66/pam_2017_v44_br_informativo.pd $f$

KJELDSEN P.; BARLAZ M.A.; ROOKER A.P.; BAUN A.; LEDIN A.; CHRISTENSEN T.H. Present and long-term composition of MSW landfill leachate: a review. Crit. Rev. Env. Sci. Tec. 2002; 32(4):297-336.

LAM S.S.; LIEW R.K.; CHENG C.K.; RASIT N.; OOI C.K.; MA N.L. et al. Pyrolysis production of fruit peel biochar for potential use in treatment of palm oil mill effluent. J. Environ. Manage. 2018; 213:400-8.

MACARTHUR E. Towards the circular economy, economic and business rationale for an accelerated transition. Cowes: Ellen MacArthur Foundation; 2013. 96 p.

MARTIN M.J.; SERRA E.; ROS A.; BALAGUER M.D.; RIGOLA M. Carbonaceous adsorbents from sewage sludge and their application in a combined activated sludge-powdered activated carbon (AS-PAC) treatment. Carbon. 2004; 42(7):1389-94. 
MARTÍNEZ E.J.; ROSAS J.G.; SOTRES A.; MORAN A.; CARA J.; SÁNCHEZ M.E.; et al. Codigestion of sludge and citrus peel wastes: Evaluating the effect of biochar addition on microbial communities. Biochem. Eng. J. 2018; 137:314-25.

MARTINS T.H.; SOUZA T.S.; FORESTI E. Ammonium removal from landfill leachate by Clinoptilolite adsorption followed by bioregeneration. J. Environ. Chem. Eng. 2017; 5(1):638.

MAROUŠEK J.; STRUNECKÝ O.; STEHEL V. Biochar farming: defining economically perspective applications. Clean Technol. Environ. Policy. 2019:1-7.

MIRABELLA N.; CASTELLANI V.; SALA S. Current options for the valorization of food manufacturing waste: a review. J. Cleaner Prod. 2014; 65:28-41.

MIRELES S.; PARSONS J.; TRAD T.; CHENG C.L.; KANG J. Lead removal from aqueous solutions using biochars derived from corn stover, orange peel, and pistachio shell. International J. Environ. Sci. Technol. 2019; 16(10): 5817-26.

MOCELIN C. Pirólise de lodo de esgoto sanitário: produção de adsorvente e óleos combustíveis [dissertation]. Curitiba: Programa de Pós-Graduação em Engenharia Mecânica e de Materiais/UTFPR; 2007. $112 \mathrm{p}$.

PRADO L.L. Utilização de lodo de esgoto pirolisado como adsorvente de amônio de lixiviado de aterro sanitário [dissertation]. Curitiba: Setor de Ciências Agrárias/UFPR; 2018. 68 p.

STEINER C. Biochar carbono sequestration. University of Georgia, Biorefining and Carbon Cycling Program, Athens, GA. 2008; 30602.

TRAN H.N.; YOU S.J.; CHAO H.P. Effect of pyrolysis temperatures and times on the adsorption of cadmium onto orange peel derived biochar. Waste Manage. Res. 2016; 34(2):129-38.

UCHIMIYA M.; WARTELLE L.H.; KLASSON K.T.; FORTIER C.A.; LIMA I.M. Influence of pyrolysis temperature on biochar property and function as a heavy metal sorbent in soil. J. Agric. Food. Chem. 2011; 59(6): 2501-10.

WANG Z.; LIU K.; XIE L.; ZHU H.; J S.; SHU X. Effects of residence time on characteristics of biochars prepared via co-pyrolysis of sewage sludge and cotton stalks. J. Anal. Appl. Pyrolysis. 2019; 142:104659. 